\section{Preparation and Characterization of $\left(\mathrm{C}_{6} \mathrm{H}_{5} \mathrm{CH}_{2} \mathrm{CH}_{2} \mathrm{NH}_{3}\right)_{2} \mathrm{SnI}_{4}$ and $\left(\mathrm{C}_{6} \mathrm{H}_{5} \mathrm{CH}_{2} \mathrm{CH}_{2} \mathrm{NH}_{3}\right)_{2} \mathrm{SnBr}_{4}$}

G. C. Papavassiliou*, J. B. Koutselas, and D. J. Lagouvardos

Theoretical and Physical Chemistry Institute, National Hellenic Research Foundation, 48, Vassileos Constantinou Ave.,

Athens 11635, Greece

Z. Naturforsch. 48b, 1013-1014 (1993); received March 25, 1993

Organometallic Compounds,

Layered Compounds,

Two-Dimensional Semiconductors

The title compounds were prepared in crystalline form and characterized analytically and spectroscopically.

Compounds $\mathrm{CH}_{3} \mathrm{NH}_{3} \mathrm{PbCl}_{3}, \quad \mathrm{CH}_{3} \mathrm{NH}_{3} \mathrm{PbBr}_{3}$, $\mathrm{CH}_{3} \mathrm{NH}_{3} \mathrm{PbI}_{3}, \quad \mathrm{CH}_{3} \mathrm{NH}_{3} \mathrm{SnBr}_{3}, \quad \mathrm{CH}_{3} \mathrm{NH}_{3} \mathrm{SnI}_{3}$, $\mathrm{CsSnI}_{3}$ etc. have been known for a long time [1-4]. $\mathrm{CH}_{3} \mathrm{NH}_{3} \mathrm{SnI}_{3}$ and $\mathrm{CsSnI}_{3}$ are metallic [2], while the rest are (three-dimensional) semiconductors [1-4]. In the last years, compounds of the formulas $\left(\mathrm{C}_{6} \mathrm{H}_{5} \mathrm{CH}_{2} \mathrm{CH}_{2} \mathrm{NH}_{3}\right)_{2} \mathrm{PbX}_{4}$ and $\left(\mathrm{CH}_{3} \mathrm{NH}_{3}\right)$ $\left(\mathrm{C}_{6} \mathrm{H}_{5} \mathrm{CH}_{2} \mathrm{CH}_{2} \mathrm{NH}_{3}\right)_{2} \mathrm{~Pb}_{2} \mathrm{I}_{7}$ (where $\mathrm{X}=\mathrm{Cl}, \mathrm{Br}$, I) and similar with $\mathrm{C}_{n} \mathrm{H}_{2 n+1} \mathrm{NH}_{3}$ or $\mathrm{H}_{3} \mathrm{NC}_{n} \mathrm{H}_{2 n} \mathrm{NH}_{3}$ $(n=4,6,8,9,10 \ldots)$ instead of $\mathrm{C}_{6} \mathrm{H}_{5} \mathrm{CH}_{2} \mathrm{CH}_{2} \mathrm{NH}_{3}$, have been prepared and their two-dimensional semiconductor behaviour has been established (see [4-8] and refs. therein). In $\left(\mathrm{C}_{6} \mathrm{H}_{5} \mathrm{CH}_{2} \mathrm{CH}_{2} \mathrm{NH}_{3}\right)_{2} \mathrm{PbI}_{4}$, for example, the two-dimensional networks of $\mathrm{PbI}_{4}$, forming perovskite-type components (anions), correspond to quantum wells, while alkylammonium chains (cations) play the role of barriers and sandwich the wells. Also, in

$\left(\mathrm{CH}_{3} \mathrm{NH}_{3}\right)\left(\mathrm{C}_{6} \mathrm{H}_{5} \mathrm{CH}_{2} \mathrm{CH}_{2} \mathrm{NH}_{3}\right)_{2} \mathrm{~Pb}_{2} \mathrm{I}_{7}$ the cation/ anion $\left(\mathrm{CH}_{3} \mathrm{NH}_{3} / \mathrm{Pb}_{2} \mathrm{I}_{7}\right)$ layers alternate with cation $\left(\mathrm{C}_{6} \mathrm{H}_{5} \mathrm{CH}_{2} \mathrm{CH}_{2} \mathrm{NH}_{3}\right)$ layers [7]. Recently, compounds of the formulas $\left(\mathrm{C}_{\mathrm{n}} \mathrm{H}_{2 \mathrm{n}+1} \mathrm{NH}_{3}\right)_{2} \mathrm{SnX}$ and $\left(\mathrm{CH}_{3} \mathrm{NH}_{3}\right)\left(\mathrm{C}_{n} \mathrm{H}_{2 n+1} \mathrm{NH}_{3}\right)_{2} \mathrm{Sn}_{2} \mathrm{I}_{7}$ have been prepared in powdered form and their optical properties reported [4]. The narrow excitonic absorption and luminescence bands is a characteristic feature of this kind of materials. In this paper the preparation of $\left(\mathrm{C}_{6} \mathrm{H}_{5} \mathrm{CH}_{2} \mathrm{CH}_{2} \mathrm{NH}_{3}\right)_{2} \mathrm{SnI}_{4}$ and $\left(\mathrm{C}_{6} \mathrm{H}_{5} \mathrm{CH}_{2} \mathrm{CH}_{2} \mathrm{NH}_{3}\right)_{2} \mathrm{SnBr}_{4}$, in pure crystalline form, as well as their analytical and spectroscopic data are reported.

\footnotetext{
* Reprint requests to Prof. G. C. Papavassiliou.
}

Verlag der Zeitschrift für Naturforschung,

D-72072 Tübingen

0932-0776/93/0700-1013/\$ 01.00/0

\section{Experimental}

\section{Precursors and instrumentation}

Precursors $\mathrm{C}_{6} \mathrm{H}_{5} \mathrm{CH}_{2} \mathrm{CH}_{2} \mathrm{NH}_{3} \mathrm{I}$ and

$\mathrm{C}_{6} \mathrm{H}_{5} \mathrm{CH}_{2} \mathrm{CH}_{2} \mathrm{NH}_{3} \mathrm{Br}$ were prepared by treatment of $\mathrm{C}_{6} \mathrm{H}_{5} \mathrm{CH}_{2} \mathrm{CH}_{2} \mathrm{NH}_{2}$ (2-phenylethylamine, Fluka 77900) with aqueous solution of $\mathrm{HI}$ and $\mathrm{HBr}$, respectively. The excess of $\mathrm{HI}$ and $\mathrm{HBr}$ and $\mathrm{H}_{2} \mathrm{O}$ as well as the impurities of $\mathrm{Br}$ and I were removed by heating the compounds at $\mathrm{ca} .60^{\circ} \mathrm{C}$ for several days. They were recrystallized from acetonitrile. $\mathrm{SnI}_{2}$ and $\mathrm{SnBr}_{2}$ were prepared and purified according to the literature methods [9-11]. Also commercial products (Ventron $\mathrm{SnI}_{2}, 71112$ and Ventron $\mathrm{SnBr}_{2}$, 71110) were used without purification. Absorption spectra were recorded on a Varian model 2390 spectrophotometer and luminescence spectra on a Jobin-Yvon model HG2S Raman spectrophotometer, using an argon laser (excitation line $454.4 \mathrm{~nm})$.

\section{Preparation of $\left(\mathrm{C}_{6} \mathrm{H}_{5} \mathrm{CH}_{2} \mathrm{CH}_{2} \mathrm{NH}_{3}\right)_{2} \mathrm{SnI}_{4}$ and $\left(\mathrm{C}_{6} \mathrm{H}_{5} \mathrm{CH}_{2} \mathrm{CH}_{2} \mathrm{NH}_{3}\right)_{2} \mathrm{SnBr}_{4}$}

A mixture of $\mathrm{C}_{6} \mathrm{H}_{5} \mathrm{CH}_{2} \mathrm{CH}_{2} \mathrm{NH}_{3} \mathrm{I}(540 \mathrm{mg}, 2.16$ $\mathrm{mmol})$ and $\mathrm{SnI}_{2}(373 \mathrm{mg}, 1 \mathrm{mmol})$ in acetonitrile $(10 \mathrm{ml})$ was heated at the reflux temperature with stirring under an argon atmosphere. A part of the solvent $(c a .4 \mathrm{ml})$ was removed with a stream of argon at $c a .75^{\circ} \mathrm{C}$ and the remaining pale yellow solution was cooled slowly at $10^{\circ} \mathrm{C}$. The precipitate was filtered and dried at $c a .40^{\circ} \mathrm{C}$ under an argon atmosphere to give $610 \mathrm{mg} \mathrm{(70 \% )} \mathrm{of}$

$\left(\mathrm{C}_{6} \mathrm{H}_{5} \mathrm{CH}_{2} \mathrm{CH}_{2} \mathrm{NH}_{3}\right)_{2} \mathrm{SnI}_{4}$ as brown-golden crystalline plates, m.p. $210^{\circ} \mathrm{C}$.

Analysis: $\mathrm{C}_{16} \mathrm{H}_{24} \mathrm{~N}_{2} \mathrm{I}_{4} \mathrm{Sn}$

Calcd C22.07 $\mathrm{H} 2.78$ N3.22 I $58.30 \%$,

These crystals remain stable for a long time under an argon atmosphere.

$\left(\mathrm{C}_{6} \mathrm{H}_{5} \mathrm{CH}_{2} \mathrm{CH}_{2} \mathrm{NH}_{3}\right)_{2} \mathrm{SnBr}_{4}$ was prepared by the same method from $\mathrm{C}_{6} \mathrm{H}_{5} \mathrm{CH}_{2} \mathrm{CH}_{2} \mathrm{NH}_{3} \mathrm{Br}$ and $\mathrm{SnBr}_{2}$; yellow crystalline plates; m.p. $183{ }^{\circ} \mathrm{C}$.

Analysis: $\mathrm{C}_{16} \mathrm{H}_{24} \mathrm{~N}_{2} \mathrm{Br}_{4} \mathrm{Sn}$

Calcd C 28.15 H3.54 N4.14 Br46.82\%,

Found C27.97 H3.61 N4.37 Br46.90\%.

These crystals are more stable in air than those of the $\mathrm{SnI}_{4}$-analogs. The method can also be applied for the preparation of $\left(\mathrm{C}_{6} \mathrm{H}_{5} \mathrm{CH}_{2} \mathrm{CH}_{2} \mathrm{NH}_{3}\right)_{2} \mathrm{PbI}_{4}$ in crystalline form. Attempts for the preparation of $\left(\mathrm{CH}_{3} \mathrm{NH}_{3}\right)\left(\mathrm{C}_{6} \mathrm{H}_{5} \mathrm{CH}_{2} \mathrm{CH}_{2} \mathrm{NH}_{3}\right)_{2} \mathrm{Sn}_{2} \mathrm{X}_{7}$ in a pure crystalline form were unsuccessful. Instead, polycrystalline powders of the compounds were obtained by this method. 


\section{Results and Discussion}

In contrast to the cases of $\mathrm{Sn}$ compounds containing long-chain anions, $\left(\mathrm{C}_{6} \mathrm{H}_{5} \mathrm{CH}_{2} \mathrm{CH}_{2} \mathrm{NH}_{3}\right)_{2} \mathrm{SnI}_{4}$ and $\left(\mathrm{C}_{6} \mathrm{H}_{5} \mathrm{CH}_{2} \mathrm{CH}_{2} \mathrm{NH}_{3}\right)_{2} \mathrm{SnBr}_{4}$ were obtained in pure crystalline form. X-ray powder-diffraction diagrams showed that $\left(\mathrm{C}_{6} \mathrm{H}_{5} \mathrm{CH}_{2} \mathrm{CH}_{2} \mathrm{NH}_{3}\right)_{2} \mathrm{SnI}_{4}$ is isostructural with $\left(\mathrm{C}_{6} \mathrm{H}_{5} \mathrm{CH}_{2} \mathrm{CH}_{2} \mathrm{NH}_{3}\right)_{2} \mathrm{PbI}_{4}$ [7]. Also, there are similarities in the optical absorption and luminescence spectra. Fig. 1 a shows the optical absorption spectrum of a thin deposit of $\left(\mathrm{C}_{6} \mathrm{H}_{5} \mathrm{CH}_{2} \mathrm{CH}_{2} \mathrm{NH}_{3}\right)_{2} \mathrm{SnI}_{4}$ obtained by rubbing some crystals of the compound on a quartz plate, and Fig. 1 a shows the corresponding luminescence spectrum. The luminescence spectrum of a single crystal or of a polycrystalline pellet is the same as that of a thin deposit. Also, the spectra of deposits obtained by melting stoichiometric amounts of the corresponding precursors on a quartz or glass plate are the same as those of Fig. 1. The dc-conductivity on a compressed polycrystalline pellet was found to be at least one order of magnitude higher than that of the $\mathrm{PbI}_{4}$-analogs. Similar results were obtained for $\left(\mathrm{C}_{6} \mathrm{H}_{5} \mathrm{CH}_{2} \mathrm{CH}_{2} \mathrm{NH}_{3}\right)_{2} \mathrm{SnBr}_{4}$; the absorption bands occur at shorter wavelengths than those of $\mathrm{SnI}_{4}$-analogs. Details of the X-ray crystal structure determination and physical properties of these new

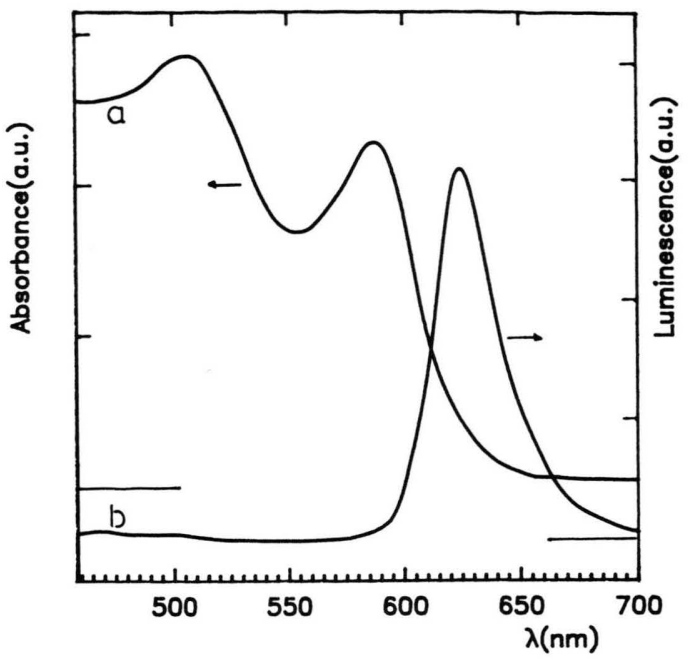

Fig. 1. Optical absorption spectrum (a) and luminescence spectrum (b) of $\left(\mathrm{C}_{6} \mathrm{H}_{5} \mathrm{CH}_{2} \mathrm{CH}_{2} \mathrm{NH}_{3}\right)_{2} \mathrm{SnI}_{4}$ at room temperature.

semiconductor compounds will be reported elsewhere.

We thank Dr. V. Psycharis for X-ray powder-diffraction diagrams.
[1] D. Weber, Z. Naturforsch. 33b, 1443 (1978); 33b, 862 (1978); 34 b, 939 (1979).

[2] K. Yamada, K. Matsui, T. Tsuritani, T. Okuda, and S. Ichiba, Z. Naturforsch. 45 a, 307 (1990).

[3] H. J. Haupt, K. Heidrich, H. Künzel, and P. Mauersberger, Z. Phys. Chem. Neue Folge 110, 63 (1978).

[4] G. C. Papavassiliou, A. P. Patsis, D. J. Lagouvardos, and I. B. Koutselas, Synth. Metals 57, 3889 (1993).

[5] X. Hong, T. Ishihara, and A. V. Nurmikko, Phys. Rev. B 45, 6961 (1992).

[6] T. Ishihara, X. Hong, J. Ding, and A. V. Nurmikko, Surf. Sci. 267 (1992).
[7] J. Calabrese, N. L. Jones, R. L. Harlow, N. Herron, D. Thorn, and Y. Wang, J. Am. Chem. Soc. 113, 2328 (1991).

[8] Ch.-Q. Xu, T. Kondo, H. Sakakura, K. Kumata, Y. Takahashi, and R. Ito, Sol. St. Commun. 79, 245 (1991).

[9] W. Moser and I. C. Irerena, Chem. Commun. 26 (1969).

[10] P. Pascal (ed.) "Nouveau Traité de Chimie Minérale", Vol. 8, Masson et Cie, Paris (1963).

[11] J. W. Mellor (ed.): A Comprehensive Treatise on Inorg. and Theor. Chemistry, Vol. 7, Longmans, London (1960). 